TA'LIMUNA. Vol.7, No. 2, September 2018 P-ISSN 2085-2975

E-ISSN 2622-9889

\title{
RELEVANSI PEMIKIRAN MAQASHID AL-SYARI'AH JASSER AUDA TERHADAP SISTEM PENDIDIKAN ISLAM MULTIDISIPLINER
}

Siti Mutholingah ${ }^{1}$, Muh. Rodhi Zamzami ${ }^{2}$

STAI Ma'had Aly Al-Hikam Malang (Penulis 1)

sitimutholiah@staima-alhikam.ac.id

STAI Ma'had Aly Al-Hikam Malang (Penulis 2)

mrzamzami@gmail.com

\begin{abstract}
Abstrak
Perkembangan zaman tentu memiliki dampak dalam berbagai aspek kehidupan umat Islam, termasuk dalam konteks keilmuan Islam. Studi tentang tujuan mendasar dari hukum Islam (maqashid al-syariah) dan produk hukum Islam (fiqh) tentu akan semakin dibutuhkan dalam rangka memenuhi kebutuhan hukum Islam yang semakin dihadapkan dengan fenomena yang tidak terjadi pada saat Nabi, masa teman, periode tabi'iin, atau periode tabi'in tabi. Menurut beberapa ulama ushul dan ulama fiqih Islam dari era sekarang (kontemporer) menganggap bahwa ada beberapa maqashid al-syari'ah dan hukum Islam (fiqh) yang harus ditinjau karena mereka kurang relevan jika diimplementasikan dalam konteks kehidupan Muslim hari ini. Salah satu ulama ushul fikih kontemporer adalah Jasser Auda. Hal utama yang mendasari mengapa Jasser Auda ingin meninjau maqashid al-sharia klasik, menurut Jasser Auda maqashid al-sharia klasik yang mencakup hifdz aldiin, hifdz al-nafs, hifdz al-aql, hifdz al-nasl, dan hifdz al-maal, masih cenderung terlalu umum, individual dan tidak mengandung nilai universal seperti prinsip keadilan dan kebebasan.
\end{abstract}

Keywords; maqashid al syari'ah, pendidikan Islam multidisipliner

\footnotetext{
${ }^{1}$ Siti Mutholingah (STAI Ma'had Aly Al-Hikam Malang)

${ }^{2}$ Muh. Rodhi Zamzami (STAI Ma'had Aly Al-Hikam Malang)
} 


\section{Pendahuluan}

Perkembangan manusia dan budaya tentunya akan membawa dampak dalam berbagai aspek kehidupan, termasuk di dalamnya kajian terhadap hukum-hukum Islam (fiqh) maupun filsafat hukum Islam (ushul fiqh). Para ulama ushuliyyin telah berijtihad sehingga melahirkan maqashid al-syaria'ah sebagai orientasi dari segala produk hukum Islam pada masa itu tentunya tidak terlepas dari konteks sosial budaya pada masa itu. Hal ini dikarenakan suatu hukum muncul sebagai jawaban dari fenomena pada saat itu sekaligus sebagai problem solving permasalahan-permasalahan yang muncul pada saat itu pula.

Tentunya hal ini akan membutuhkan pengkajian ulang terhadap maqashid al-syariah klasik yang telah dirumuskan oleh para ulama terdahulu jika dihadapkan pada kehidupan sosial dan budaya manusia saat ini, yang tentunya sudah mengalami berbagai perubahan dan struktur sosial yang berbeda jika dibandingkan dengan kondisi sosial ulama terdahulu ketika mencetuskan maqashid al-syariah. Dan karena itulah, beberapa ulama kontemporer sekarang ini banyak memberikan perhatian sekaligus pengkajian terhadap filsafat hukum Islam yang telah ada untuk dikaji ulang dan disesuaikan dengan perkembangan zaman saat ini. Karena mereka menganggap bahwa ada persoalan-persoalan yang muncul saat ini yang tidak bisa diselesaikan jika hanya bersandar pada maqashid al-syari'ah hasil ijithad ulama terdahulu dan perlu ada reorientasi kaidah dalam maqashid al-syari'ah yang disesuaikan dengan kebutuhan dan konteks sosial budaya umat zaman sekarang ini.

Dari sinilah, Jasser Auda muncul sebagai salah satu ulama kontemporer yang meberikan perhatian yang besar terhadap peninjauan kembali maqashid al-syari'ah sebagai filsafat hukum Islam dari berbagai disiplin (multidisipliner) ${ }^{3}$ dengan menggunakan suatu pendekatan sistem. ${ }^{4}$ Sehingga

3 Multidisipliner dalam kajian maqashid as syaria'ah yang digunakan oleh Jasser Auda yaitu bahwa dalam penetuan maqashid as-syariah bisa dikaji dari berbagai sudut pandang disiplin keilmuan seperti ushul fiqh dan filsafat yang dalam hal ini Auda menggunakan filsafat sistem.

${ }^{4}$ Pendekatan sistem yang digunakan oleh Jasser Auda yaitu sistem merupakan sebuah disiplin baru cabang dari ilmu kognitif "cognitive science" yang bebas (independent) dan memuat berbagai cabang disiplin yakni antara teori sistem dan analisis sistemik. Maksud independen di sini yaitu bahwa teori sistem yang dimunculkan oleh Jasser Auda merupakan sisi lain (atau tidak terikat) dari pendekatan filosofis (anti-modernisme) yang sangat kritis terhadap modernisme tetapi juga berbeda dari teori post-modern. (Jasser Auda, Maqasid al-Shariah as Philosophy of Islamic Law: A Systems Approach, (digital book), (London: the International Institut of Islamic Thougth, 2007), hlm. xxvi 
maqashid al-syariah yang sudah dimunculkan para ulama terdahulu bisa direvitalisasikan dengan pemberian penambahan-penambahan yang relevan dengan persoalan umat saat ini, yang tentunya dari aspek sosial budaya jelas jauh berbeda dengan kondisi sosial budaya pada masa ulama-ulama terdahulu.

Selanjutnya pendidikan Agama Islam sebagai suatu disiplin ilmu tentunya tidak terlepas dari suatu sistem, oleh karena itu paradigma pengembangan pendidikan Agama Islam hendaknya juga dikaji melalui suatu pendekatan sistem sebagaimana telah dikembangkan oleh Jasser Auda dalam mengembangkan maqashid al-syari'ah melalui pendekatan sistem yang multidispiliner tersebut. Dengan demikian, pendidikan Agama Islam nantinya bisa lebih bersifat holistik dan multidisipliner. Artinya pendidikan Agama Islam bisa dikaji dengan berbagai sudut pandang disiplin keilmuan yang tentunya sangat bermanfaat bagi pembinaan peserta didik di era modern ini yang dalam kehidupannya selalu dihadapkan dengan berbagai macam disiplin keilmuan, yang tentunya sebenarnya di dalam al-Qur'an sendiri (sebagai sumber utama dari pendidikan Agama Islam) sudah mengisyaratkan berbagai macam displin keilmuan untuk dikembangkan. Pada pembahasan ini penulis batasi pada pemikiran Jasser Auda mengenai maqashid al syari'ah melalui pendekaran sistem multidisipliner, relevansi pemikiran Jasser Auda dalam pendidikan Islam.

\section{Pemikiran Jasser Auda mengenai Maqashid al-Syari'ah melelui Pendekatan Sistem secara Multidisipliner}

\section{Biografi Jasser Auda}

Jasser Auda adalah seorang cendekiawan muslim kontemporer yang memberikan warna baru dalam perkembangan hukum Islam, khususnya dalam hal ini mengenai konsep maqashid al-Syari'ah. Beliau adalah seorang tokoh yang sangat terkenal di dunia Islam maupun di barat. Hal ini sesungguhnya tidak terlepas dari pendidikan maupun karier beliau yang ditempuh di Kairo yang berlanjut ke Kanada hingga ke London.

Jasser Auda dilahirkan di Kairo, Mesir. ${ }^{5}$ Pendidikan Jaser Auda dimulai di Kairo. Beliau adalah seorang sarjana teknik di universitas Kairo pada tahun 1998. Selain itu pada tahun 2001 beliau mendapat gelar B.A. (sarjana muda) diperoleh dari program studi Islamic Studies pada Islamic American University di Amerika Serikat. Kemudian pada tahun 2004, beliau menyelesaikan Master Fiqh dari Universitas Islam Amerika di Michigan dengan fokus kajian Maqasid

${ }^{5}$ Hengki Ferdiansyah, Jasser Auda Imam al Ghazali masa kini, (online), Tersedia : http://www.muslimedianews.com/2016/08/jasser-auda-imam-al-ghazalimasa-kini.html, diakses 30 November 2017 
al-Syari'ah atau Tujuan Hukum Islam. Selanjutnya pada tahun 2006 beliau memperoleh gelar Ph.D di Waterloo University, Kanada, dengan fokus kajian Analisis Sistem. Gelar Ph.D yang kedua diperoleh di University of Wales, Inggris, dengan konsentrasi Filsafat Hukum Islam, tahun 2008. ${ }^{6}$ Ketika di Kairo, Beliau juga melakukan talaqqi klasik di masjid Jami' al-Azhar (Kairo, Mesir) yakni berupa kegiatan menghafal Qur'an, mengkaji kitab hadits alBukhari dan Muslim, fikih, Isnad dan Takhrij serta Usul Fikih. ${ }^{7}$

Jasser Auda adalah pendiri Maqashid Research Center sekaligus sebagai direkturnya di London, Inggris. ${ }^{8}$ Selain itu, Karier Jasser Auda adalah meliputi Presiden Institut Maqasid Global, yang merupakan sebuah kelompok pemikir yang terdaftar di Amerika Serikat, Inggris, Malaysia dan Indonesia, dan memiliki program pendidikan dan penelitian di sejumlah negara. Beliau adalah anggota Dewan Fiqih Amerika Utara, Dewan Fatwa Eropa dan seorang rekan di Akademi Fiqih India. Beliau juga bekerja sebagai profesor di universitas-universitas di Waterloo, Carleton dan Ryerson di Kanada, Alexandria di Mesir, Perdamaian Internasional di Afrika Selatan, Universitas Islam di Sanjaq, Qatar Faculty of Islamic Studies, Universitas Amerika Sharjah di UAE dan Universitas Bahrain. Beliau mengajar Islam dan hukumnya di berbagai negara, termasuk di Indonesia. ${ }^{9}$

Adapun karya-karya beliau kurang lebih 25 buku yang ditulis dalam bahasa Arab dan Inggris, beberapa di antaranya diterjemahkan ke 25 bahasa. ${ }^{10}$ Terdapat beberapa karya intelektualnya telah dipublikasikan secara massal. Diantaranya yaitu berjudul Antara Syariat dan Politik: Sejumlah Pertanyaan Pasca Revolusi, ljtihad berdasarkan al-Maqasid, Mengkritik Teori al- Naskh, Kata-kata Mutiara: Sebuah Perjalanan dengan Ibnu 'Ama, Kontekstualisasi Islam di Inggris, Pendekatan-Pendekatan Internasional terhadap Studi Islam di Perguruan Tinggi, Ekonomi Pengetahuan dan alMaqasid al-Syariah, Fikih Aspek Ekonomi pada Krisis Semesta Kontemporer, Fikih Lingkungan: Beberapa Pengantar Dasar. ${ }^{11}$ Adapun buku terakhirnya dalam bahasa Arab (dan Urdu) adalah Fiqh al-Maqasid, dan juga dalam bahasa Inggris adalah Maqasid al-Shariah as Philosophy of Islamic Law: a

\footnotetext{
${ }^{6}$ Jasser Audah, Al-Maqashid untuk Pemula, Terj. Ali Abdelmo'im, (Yogyakarta: SUKA-Press, 2013), hlm. x

${ }^{7}$ Ibid., hlm. 137-140

8 Ibid., untuk informasi lebih banyak mengenai Jasser Auda dapat diakses di www.jasserauda.net dan juga www.maqasid.net.

9 Jasser Auda, biografi, (online), Tersedia : http://www.jasserauda.net/ portal/biography/?lang=en), diakses 30 November 2017

${ }^{10}$ Ibid.

${ }^{11}$ Jasser Audah, Al-Maqasid untuk Pemula.., hlm. 139 dan 140
} 
Systems Approach. Kedua karya ilmiah ini, diterbitkan oleh Institut Pemikiran Islam Internasional (IIIT) di London pada tahun 2007. ${ }^{12}$

Jika dilihat dari latar belakang pendidikan dan karya-karya beliau di atas, bisa dijadikan landasan untuk membaca pemikiran beliau yang memang memfokuskan kajiannya pada wilayah kajian hukum Islam kontemporer. Sehingga sangat wajar dan sangat pantas jika Jasser Auda mempunyai ijtihad untuk memperbaharui dan mereformasi hukum Islam tradisional ke dalam konteks saat ini melalui sistem secara multidipliner yang memang latar belakang pendidikan S3 nya adalah kajian filsafat sistem dan hukum Islam, dan itu berada di negara barat yang tentunya kondisinya kondisinya sangat berbeda dengan negara-negara Islam sebagaimana dilahirkannya maqashid al-syariah klasik.

\section{Latar Belakang Pemikiran Jasser Auda mengenai Maqashid al-Syari'ah}

Pemikiran Jasser Auda dalam mengkaji ulang maqashid al-syariah sebagai filsafat hukum Islam ini dilatarbelakangi oleh anggapannya terhadap maqashid al-syari'ah klasik sebagaimana telah dicetuskan para ulama terdahulu seperti as-Syatibi dan lain sebagainya sudah tidak relevan dengan kondisi umat manusia saat ini dikarenakan zaman semakin berkembang, sehingga perlu adanya reorientasi maupun revisi terhadap maqashid alsyariah tersebut. Menurutnya, maqashid al-syariah klasik tidak holistik melainkan lebih bersifat aplikasi tertentu, kemudian lebih menekankan aspek literal daripada moral, hanya bersifat satu dimensi dan tidak multi dimensi, lebih dekonstruksi daripada rekonstruksi. ${ }^{13}$ Anggapan Jasser Auda tersebut tentunya bukan hanya sekedar anggapan yang tidak beralasan. Tentunya ada alasan yang kuat yang melandasinya.

Adapun alasan ketidakrelevanan maqashid al-syari'ah klasik tersebut, menurut Jasser Auda dapat dilihat dari beberapa aspek diantaranya:

a) Ruang lingkup maqashid klasik adalah keseluruhan hukum Islam, namun mereka gagal memasukkan tujuan khusus untuk keputusan tunggal atau kelompok skrip yang mencakup topik atau bab figh tertentu;

b) Maqashid klasik cenderung bersifat individu dan kurang bersifat masyarakat, kemanusian dan umum;

12 King Faisal Sulaiman, Maqasid Al-Shariah Perspektif Jasser Auda,(online), Tersedia : http://kingfaisalsulaiman.com/maqasid-al-shariah-perspektif-jasser-auda/, diakses 30 November 2017

13 Jasser Auda, Maqasid al-Shariah as Philosophy of Islamic Law: A Systems Approach, (digital book), (London: the International Institut of Islamic Thougth, 2007), hlm. xxvii 
c) Maqashid klasik tidak memuat kebanyakan nilai-nilai dasar dan universal seperti prinsip keadilan dan kebebasan;

d) Maqashid klasik disimpulkan dari mempelajari literatur figh dan bukan sumber aslinya. ${ }^{14}$

Menurut Auda, maqashid al-syariah klasik yang lebih bersifat individual yakni protection (perlindungan) dan perservation (pelestarian) itu harus direorientasikan menjadi maqashid yang lebih bersifat nilai universal, lebih bersifat kemasyarakatan dan kemanusiaan (hak asasi manusia dan kebebasan). ${ }^{15}$ Dan reorientasi inilah kiranya yang menjadi pembeda antara pemikiran Auda dengan pemikiran ulama-ulama ushul fiqih terdahulu.

Pemikiran Auda ini sesungguhnya juga tidak terlepas dari kondisi sosial yang terjadi di daerah di mana beliau menempuh program doktornya, yaitu di London. Pemikiran beliau dilatarbelakangi oleh maraknya aksi kriminal dan terorisme yang terjadi di barat khussunya di London pada waktu itu (2007) dengan mengatasnamakan "hukum Islam/Is/amic law", dan itu dilakukan oleh orang yang beridentitas muslim. Sehingga orang barat banyak yang beranggapan bahwa hukum Islam syarat dengan kriminalitas dan pembunuhan terhadap orang lain. ${ }^{16}$ Selain itu, berdasarkan indeks HDI (Human Development Indeks) bahwa umat muslim menenpati level yang masih rendah apalagi faktor-faktor determinan yang dipakai dalam HDI tersebut meliputi tingkat buta aksara, pendidikan, partisipasi politik, ekonomi dan pemberdayaan atau emansipasi wanita, umat Islam masih berada dibawah standar minimal. ${ }^{17}$

Tentunya hal ini menggugah Jasser Auda untuk memberikan pemahaman kembali terhadap masyarakat mengenai apa itu "Islamic law/Syari'ah" atau hukum Islam yang sesungguhnya dan bagaimana syari'ah memegang peranan penting dalam menghadapi kasus-kasus kriminalitas yang mengatasnamakan "hukum Islam" tersebut. Auda meyakini bahwa hukum Islam merupakan kemudi yang menjadi penggerak masyarakat yang adil, berdaya cipta, berkembang, manusiawi, spiritual, bersih, kohesif, ramah, dan sangat demokratis. Maksud Auda mendefinisikan kembali hukum Islam tersebut adalah untuk meyakinkan kepada masyarakat bahwa "hukum Islam" itu bukan sesuatu yang memerintahkan pada tindakan kriminal. Meskipun Auda tidak memungkiri bahwa selama perjalanannya di berbagai negara, dia

\footnotetext{
${ }^{14}$ Ibid., hlm. 4

${ }^{15}$ Ibid., hlm. 248

${ }^{16}$ Ibid., hlm. xxi

${ }^{17}$ Ibid., hlm. xxii
} 
sedikit sekali menemukan bukti bahwa sesungguhnya "hukum Islam" itu demikian sempurnanya. ${ }^{18}$

Dikarenakan teori hukum Islam klasik sebagaimana dirumuskan oleh para ulama klasik oleh Auda dianggap sudah tidak relevan lagi dengan perkembangan zaman, maka menurut Auda perlu mengembangkan teori hukum Islam (maqashid al-syariah) yang relevan dan mampu mengikuti perkembangan zaman. Hal ini ditujukan agar nantinya produk hukum Islam (syari'at) yang berlandaskan pada maqashid al-syariah ini akan selalu relevan sampai kapunpun dan di manapun sebagaimana sifat dari sumber hukum Islam itu sendiri yakni al-Qur'an yaitu "صنَالِحِح لِكُلِّ زَمَانِ وَ مَكَانٍ " (benar sampai kapanpun dan di manapun).

Oleh karena itu, menurut Jasser Auda, untuk mewujudkan maqashid al-syariah yang relevan sampai kapanpun dan di manapun (زحلاحية الثريعة لكل tersebut membutuhkan suatu kata kunci (keyword). Adapun kata kunci yang paling tepat untuk mengembangkan teori hukum Islam tersebut adalah "pendekatan sistem".

Itulah beberapa hal yang melatarbelakangi Auda untuk melakukan ijtihad dan pengkajian ulang terhadap maqashid al-syariah sebagai filsafat hukum Islam (philosophy of Islamic law) dengan menggunakan pendekatan sistem yang memang menjadi basik keilmuannya.

\section{Ruang Lingkup (Fokus Kajian) Pemikiran Jasser Auda}

Dalam disertasinya ini, Jasser Auda telah menetukan ruang lingkup pemikirannya di mana dia tidak akan berbicara di luar ruang lingkup tersebut. Adapun ruang lingkup atau fokus kajian pemikiran Auda yaitu Fundamentals of Islamic law dan pendekatan sistem:

\section{a. Fundamentals of Islamic law (Ushul Fiqh)}

Auda memfokuskan kajiaanya pada wilayah ushul fiqih, meskipun dalam pembahasannya pasti akan terkait dengan fiqh, ilmu hadits, ilmu tafsir. Contohnya produk fiqih digunakan untuk mengilustrasikan dampak partikel dari teori fundamental (ushul fiqh), kemudian kaidah dari ilmu hadits dan tafsir dibahas dalam konteks hubungannya dengan ushul figh. Kemudian Maqashid (tujuan utama disyari'atkan hukum Islam terhadap mukallaf) sebagai "fundamental methodology" dari ushul fiqh itu sendiri. ${ }^{19}$

Dalam mengkaji ushul fiqih ini, Jasser Auda melakukan "critical histories of Islamic Law"yaitu ushul fiqih yang dikaji oleh Jasser Auda ini

\footnotetext{
${ }^{18}$ Ibid., hlm. xxii

${ }^{19}$ Ibid., hlm. xxv
} 
berdasarkan analisis kritis sejarah perkembangannya yakni ushul fiqih sejak zaman klasik hingga kontemporer.

1) Kajian terhadap Ushul Fiqih Periode Klasik dan Pertengahan.

Pada periode ini, Jasser Auda melakukan peninjauan secara historis baik terhadap Imam madzhab maupun produk hukum Islam (fiqih). Pada periode ini ada 9 madzhab fiqih yang beliau kaji yaitu madzhab Maliki, Hanafi, Syafi'I, Hanbali, Ja'fari, Zaidi, Dzahiri, 'Ibadi, dan Mu'tazili. ${ }^{20}$ Adapun hasil dari critical histories terhadap madzhab fiqih periode klasik dan pertengahan ini antara lain. $^{21}$

Pertama, tidak ada informasi analitis terkait produk hukum (fiqih) yang siginifikan, hal ini dikarenakan adanya perbedaan penggunaan sumber hukum (selain al-Qur'an, hadits), misalnya Maliki, Hanafi, Syafi'i dan Hanbali menggunakan ijma' dan qiyash sebagai sumber hukum, sedangkan Dzahiri hanya menggunakan al-Qur'an dan hadits.

Kedua, suatu madzhab diklasifikasikan berdasarkan apakah mereka mendukung satu sumber hukum atau yang lain, seperti, menggunakan 'ijma' atau 'istihsan'. Namun, definisi fitur (sumber hukum) ini sangat bervariasi dari satu madzhab dengan madzhab lainnyasehingga tidak dapat secara akurat digunakan sebagai dasar klasifikasi.

Ketiga, mengesampingkan dua pilihan (binary choice), misalnya terlepas dari kenyataan bahwa al-Tusi diklasifikasikan sebagai penganut madzhab 'Hanbalï,' padahal metode istinbatnya juga menganut Muktazili. Selain itu misalnya al-Ghazali diklasifikasikan sebagai penganut madzhab Syafi'i, padahal dalam praktiknya dia juga penganut Maliki, dan lain sebagainya.

Keempat, menolak faktor dimensionalitas, artinya secara historis, madzhab-madzhab dalam fiqih sebagian besar dibentuk oleh faktor-faktor seperti sistem geografi, politik, dan pengadilan. Namun, faktor-faktor ini tidak diperhitungkan dalam klasifikasi madhahib, seperti juga faktor biner lainnya.

Kelima, pengaruh (kharismatik) para imam madzhab lebih dominan berpengaruh daripada metodologi istinbath, dan teori fundamental (ushul) tidak begitu ketat diamati sebagai pendapat masing-masing para imam.

2) Kajian terhadap Ushul Fiqih Kontemporer

Meskipun Jasser Auda termasuk dalam ulama ushul kontemporer, tetapi dalam mengembangkan maqashid syariah kontemporer ini beliau juga mengkritisi ulama ushul kontemporer yang lain, seperti Rasyid Ridla, Muhammad Abduh, Bassam Tibbi, Syahrur, dan lain sebagainya. Adapun kritik beliau terhadap teori hukum Islam kontemporer.

\footnotetext{
${ }^{20}$ Ibid., hlm. 56

${ }^{21}$ Ibid., hlm. 70-71
} 
Ulama kontemporer dalam mengkaji teori hukum Islam kontemporer sangat dipengaruhi oleh ideologi mereka yakni ada yang bersifat fundamentalis, modernis, dan sekuler. ${ }^{22}$ Filosofi Barat memang memiliki dampak signifikan terhadap pengembangan teori hukum Islam kontemporer, melalui pengaruh Mohammad Abdu dan lainnya. ${ }^{23}$

Pengembangan teori hukum Islam kontemporer lebih diarahkan pada aspek kebebasan politik dan individu, pendidikan, status perempuan, peradilan pidana, legitimasi reformasi dan perubahan, dan sikap terhadap barat. ${ }^{24}$ Pengembangan teori hukum Islam kontemporer lebih mengedepankan aspek nilai modern, yang rujukannya biasanya merupakan Deklarasi Universal tentang Hak Asasi Manusia. ${ }^{25}$

Critical histories yang dilakukan oleh Jasser Auda ini kemudian ia gunakan sebagai landasan dalam mengembangkan maqashid al-syariah kontemporer versi beliau, yakni dengan mendialogkan teori hukum Islam klasik, pertengahan maupun kontemporer.

\section{b. Filsafat Sistem}

Filsafat sebagai bidang logika, dalam hal ini Auda membatasi kajiannya pada filsafat hukum dan teori post-modern. Logika adalah jantung dari pemikiran tentang hukum termasuk hukum Islam. Filsafat hukum dalam pengertian modern yang dikaji oleh Auda yaitu bagaiaman filsafat hukum Islam dapat memberikan manfaat secara konseptual maupun struktur khususnya pada pengembangan berbasis sistem yang sedang gencargencarnya dikembangkan oleh para filosof di era modern ini. Teori postmodern adalah sebuah teori "anti-modernisme" yang merupakan cabang dari filsafat yang terinspirasi dari beberapa pemikir kritis kontemporer termasuk dalam kajian hukum Islam. ${ }^{26}$

Menurut Auda, "sistem" adalah disiplin baru yang di dalamnya memuat beberapa sub-disiplin, di antaranya teori sistem dan juga analisis sistematis. Teori sistem adalah pendekatan folosofis "anti-modernism" yang mengkritisi "modernism" ${ }^{27}$ yang berbeda pula dengan teori post-modern. ${ }^{28}$

${ }^{22}$ Ibid., hlm. 146
${ }^{23}$ Ibid., hlm. 152
${ }^{24}$ Ibid., hlm. 148
${ }^{25}$ Ibid., hlm. 159
${ }^{26}$ Ibid., hlm. xxvi

${ }^{27}$ Kemunculan aliran filsafat modern dimulai pada abad 17 - $19 \mathrm{M}$, dengan tokoh yang dikenal sebagai bapak filsafat modern adalah Rene Descartes. Basis perkembangan ilmu pengetahuan pada masa itu yaitu pengedepanan fungsi akal. Menurut pandangan filsafat modern bahwa segala sesuatu bersifat kausalitas (adanya hubungan sebab akibat) [Rizal Mustansyir dan Misnal Munir, Filsafat IImu, 
Konsep dari teori sistem yang ditawarkan oleh Jasser Auda yaitu meliputi wholeness (keutuhan), multidimensionality (berbagai dimensi), opennes (keterbukaan), dan purposefulness (bertujuan). ${ }^{29}$

Kemudian terkait dengan "sistem" ini Auda juga menawarkan sebuah disiplin baru tentang "cognitive science" / ilmu kognitif. Konsep dari ilmu kognitif ini digunakan untuk mengembangkan konsep dasar dari teori maqashid al-syariah, seperti teori klasifikasi/kategorisasi" dan "cognitive nature" / sifat kognitif hukum. Selain itu "cognitive culture" / budaya kognitif

(Yogyakarta: Pustaka Pelajar, 2008) cet. 1, hlm. 71]. Secara garis besar ada 3 madzhab dalam filsafat modern yaitu rasionalisme/idealisme dan empirisme. Menurut paham rasionalisme akal merupakan alat terpenting dalam memperoleh pengetahuan sekaligus untuk menguji pengetahuan. Tokoh-tokoh penting dalam aliran rasionalisme ini yaitu Descartes, Spinoza, dan Leibniz [Ahmad Tafsir, Filsafat Umum, cet. I (Bandung: Remaja Rosda Karya, 1990), hlm. 204.]. Kebalikan dari paham rasionalisme yaitu paham empirisme. Menurut paham empirisme bahwa pengalaman merupakan sumber atau dasar dari segala sesuatu yang ada dalam pikiran manusia. Paham ini mennganggap bahwa pendapat paham rasionalisme hanya berdasarkan pada kepastian yang bersifat a priori. Pelopor dari aliran empirisme ini adalah Francis Bacon, dan selanjutnya dikembangkan oleh Thomas Hobbes, John Locke, dan David Hume.[ Amsal Bakhtiar, Filsafat IImu, cet. 9, (Jakarta: Rajawali Pers, 2010), hlm. 67

${ }^{28}$ Filsafat post-modernisme ini mulai muncul pada tahun 1970-an oleh Jeans Francois Lyotard dalam sebuah seminar diantara para ahli filsafat. Salah satu tokoh yang dianggap menjadi pengembang dalam filsafat post-modernisme ini adalah Derrida. Postmodern hadir untuk mengkritik beberapa pandangan modernisme dimana manusia telah dikendalikan secara teknis untuk dapat berfikir secara rasional yakni harus menggunakan logika, prinsip, maupun sistem pembuktian.. Hakikat manusia di masa postmodern bukan untuk membuktikan kebenaran, tapi mencari kebenaran. Salah satu produk pemikiran Derrida adalah konsep dekonstruksi yang juga tergabung dalam pandangan logosentrisme (segala sesuatu yang penting hanya simbolnya saja).[Noeng Muhadjir, Filsafat IImu ; Ontologi, Epistemologi, Axiologi,(Yogyakarta, Penerbit Rake Sarasin, 2011) cet.1 , hlm. 333-341]

${ }^{29}$ Jasser Auda, Maqasid al-Shariah as Philosophy of Islamic Law: A Systems Approach, (digital book), (London: the International Institut of Islamic Thougth, 2007), hlm. xxvi

30 Contoh teori klasifikasi yang digunakan oleh Auda yaitu teori klasifikasi/hierarki kebutuhan Abraham Maslow. Teori ini ia gunakan untuk membandingkan dengan hierarki maqashid al-syariah yang dicetuskan oleh ulama terdahulu seperti al-Syatibi. Menurut Auda, kesamaan antara teori hierarki kebutuhan Maslow dengan hierarki maqashid al-syari'ah al-Syatibi yaitu pada level tujuan adalah kemaslahatan, Jasser Auda, Maqasid al-Shariah., hlm. 4 
juga digunakan untuk mengembangkan konsep budaya / "al-"urf" dalam teori hukum Islam. ${ }^{31}$

Inilah kelebihan pemikiran Jasser Auda dibanding ulama ushul fiqih kontemporer yang lain. Beliau lebih bersifat multidisipliner dalam memandang teori hukum Islam, yakni beliau menggunakan produk keilmuan barat yaitu filsafat sistem dan teori kognitif dalam mengkaji ulang teori hukum Islam selama produk keilmuan barat tersebut tidak bertentangan dengan al-Qur'an sebagai sumber hukum Islam.

\section{Metodologi yang Digunakan oleh Jasser Auda}

Metodologi yang digunakan oleh Jasser Auda dalam melakukan kajian ini yaitu berdasarkan pada 2 teori yaitu teori tentang maqashid al-syari'ah dan pendekatan sistem.

a. Teori tentang maqashid al-syariah

Maqashid al-syari'ah (tujuan dari hukum Islam), maqashid diposisikan sebagai sebuah filsafat dan metodologi fundamental untuk menilai teori yuridis klasik dan terkini tentang hukum Islam. ${ }^{32}$

Jadi dikarenakan maqashid al-syari'ah oleh Auda diposisikan sebagai filsafat hukum Islam, maka sesungguhnya penetuan hukum Islam harus didasarkan pada maqashid sebagai tujuan utamanya.

b. Pendekatan sistem

Istilah "sistem" diambil dari Bahasa Latin yaitu dari kata "systema" dan juga dari kata "sustēma" yang berasal dari Bahasa Yunani yang artinya yaitu suatu kesatuan yang terdiri dari komponen bersama untuk mempermudah aliran informasi, materi atau energi dalam rangka mencapai suatu tujuan. ${ }^{33}$ Sedangkan dalam Kamus Besar Bahasa Indonesia, kata "sistem" diartikan sebagai suatu perangkat unsur yang saling berkaitan secara teratur sehingga membentuk suatu totalitas. ${ }^{34}$

Pendekatan sistem yang digunakan oleh Auda ini meliputi 6 fitur yang saling berkaitan yaitu sifat kognitif sistem (cognitive nature of system), keutuhan (wholeness), keterbukaan (openness), hierarki/tingkatan yang saling berkaitan (interrelated hierarchy), multidimensionalitas (multidimentionality), dan juga kebertujuan (purposefulness). Kebertujuan inilah

${ }^{31}$ Ibid. hlm. xxvi

32 lbid., hlm xxvii

${ }^{33}$ https://id.wikipedia.org/wiki/Sistem, diakses 30 November 2017

34 Kamus Besar Bahasa Indonesia (KKBI) (online), Tersedia : https://kbbi.web.id/sistem, diakses 30 November 2017 
yang menjadi inti dari fitur sistem hukum Islam itu sendiri. ${ }^{35}$ Jadi hukum Islam sebagai suatu sistem harus mencakup ke enam fitur tersebut.

Untuk mempermudah pemahaman kita mengenai pendekatan sistem ini dapat dilihat pada gambar berikut ini:

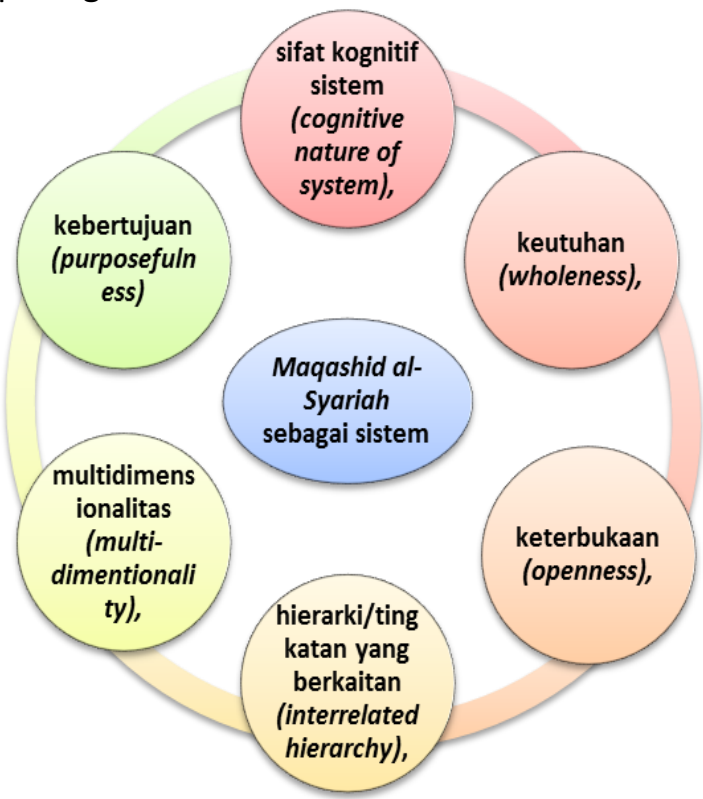

\section{Gambar 1. Fitur-fitur Pendekatan Sistem menurut Jasser Auda}

1) Sifat Kognitif Sistem Hukum Islam

Menurut Auda, hukum Islam (fiqih) merupakan hipotesis hasil konstruksi kognitif para ahli hukum "fi dhin al-faqih". Hukum Islam merupakan hasil dari penalaran dan ijtihad para ahli fiqh yang mencoba untuk mengungkap makna tersembunyi atau implikasi praktis dari syari'at yang ada di dalam al-Qur'an dan di dalam hadits. Sehingga sifat kognitif dari hukum Islam ini diperlukan dalam memvalidasi pandangan yang sangat bervariatif dalam penentuan hukum Islam. ${ }^{36}$

Maksud dari ini yaitu, dikarenakan hukum Islam itu merupakan produk hasil pemikiran dan ijtihad para ulama maka tentunya antara ulama (madzhab) satu dengan ulama yang lain tentunya ada perbedaan. Hal ini dikarenakan setiap ulama mempunyai pemikiran tersendiri yang mungkin berbeda dengan pemikiran ulama lain. Oleh karena itu, latar belakang pemikiran setiap ulama fiqh sangat berpengaruh atau menetukan produk hukum hasil ijtihadnya. Dengan demikian, dikarenakan produk dari hukum

${ }^{35}$ Jasser Auda, Maqasid al-Shariah., hlm. 250

${ }^{36}$ Ibid., hlm. 46 
Islam (fiqih) merupakan hasil dari aktivitas kognitif (yang kemungkinan bisa ada kesalahan atau kekurangannya) tentunya memungkinkan untuk diadakan kritik maupun pengkajian ulang.

2) Keutuhan Sistem Hukum Islam

Keholistikan atau keutuhan hukum Islam yakni dapat dilihat dari hujjah yang digunakan oleh para ulama ushul figh yaitu bersifat "holistic evidence" (hujjah al-kulliy) yang dijadikan pertimbangan dalam menetukan hukum Islam. Pemikiran yang holistik atau menyeluruh pun juga diperlukan dalam mengkaji filsafat hukum Islam untuk mengembangkan semantik dan ilmu kalam. ${ }^{37}$

Jadi hukum Islam ini menyangkut keseluruhan aspek baik itu terkait dengan ilmu ushul fiqh itu sendiri maupun kaitannya dengan ilmu-ilmu yang lain. Oleh karena itu dalam penetuan hukum Islam tidak boleh dilepaskan dari ilmu-ilmu agama yang lain seperti ilmu kalam. Dalam hukum Islam dibutuhkan kesatuan antara hukum dengan moralitas sehingga tercipta pendekatan yang bersifat holistik.

3) Keterbukaan Sistem Hukum Islam

Menurut Auda, tidak ada istilah penutupan pintu ijtihad dalam hukum Islam sebagaimana dikemukakan oleh para ulama klasik. Hal ini dikarenakan hukum Islam dapat dikembangkan sesuai dengan kebutuhan zaman jika memang menghadapai perubahan-perubahan baru dalam beberapa aspek kehidupan manusia. Hukum Islam bisa bersifat fleksibel sesuai dengan konteks zaman, keadaan, maupun tempat. ${ }^{38}$

Jadi, meskipun hukum Islam yang telah ada baik itu syari'at, fiqh, maupun fatwa yang dicetuskan oleh para ulama terdahulu bisa dikembangkan sesuai dengan konteks kebutuhan manusia di era sekarang ini. Selagi dalam pengembangan hukum Islam itu tetap berlandaskan pada sumber hukum Islam yang utama yakni al-Qur'an dan hadits dan tetap menjungjung tinggi maqashid al-syari'ah sebagai filsafat hukum Islam.

4) Keterkaitan antar Tingkatan dalam Hukum Islam

Meskipun dalam maqashid al-syariah sebagaimana dirumuskan oleh para ulama klasik seperti al-syatibi misalnya terdapat hiraki atau tingkatantingkatan dari maqashid yang paling mendasar yakni dzaruriyat, hajiyat, dan tahsiniyat, namun pada hakikatnya antara ketiganya saling berhubungan dan berkaitan satu sama lain. Bahkan pemenuhan salah satu kebutuhan itu harus dalam rangka mewujudkan kebutuhan dasar di bawahnya. ${ }^{39}$

\footnotetext{
${ }^{37}$ Ibid., hlm. 47

${ }^{38}$ Ibid., hlm. 47-48

${ }^{39}$ Ibid., hlm 48
} 
Untuk memudahkan pemahaman kita bisa ambil contoh antara kewajiban shalat, zakat, puasa, kemudian kebutuhan manusia untuk makan dan kebutuhan manusia untuk refreshing dalam rangka menyegarkan kembali pikiran dinilai sama-sama menjadi kebutuhan yang harus dipenuhi oleh manusia. Meskipun yang harus didahulukan adalah kewajiban shalat, zakat dan puasa, tetapi bukan berarti kebutuhan manusia untuk makan dan refreshing tidak dipenuhi.

5) Multidimensionalitas Sistem Hukum Islam

Dikarenakan sistem merupakan suatu kesatuan dari berbagai subsistem yang saling berkaitan begitu juga dengan hukum Islam yang merupakan suatu sistem maka dalam berijtihad menetukan hukum Islam harus berpikir multi-dimensi. Dalam hal ini Auda mengkritik para ulama ushul maupun ulama fiqih klasik cenderung berpikirnya hanya satu atau dua dimensi saja. Misalnya memandang segala sesuatu hanya dari sisi hitam dan putih, fisik dan metafisik, universal dan spesifik dan lain sebagainya. Misalnya dalam ta'arud al-dalalah yang terkadang ada yang menganggap ada pertentangan ayat dalam al-Qur'an. ${ }^{40}$

Padahal jika kita berpikir multidimensional maka tidak mungkin ada pertentangan ayat dalam al-Qur'an. Melainkan yang ada adalah pemahaman manusia yang terbatas pada satu atau dua aspek saja sehingga ketika memahami ayat merasa ada yang saling bertentangan.

6) Kebertujuan Sistem Hukum Islam

Dalam suatu sistem, tujuan adalah menjadi sesuatu yang paling inti. Hal ini dikarenakan suatu sistem dibentuk memang dalam rangka mencapai tujuan tertentu, begitu juga dengan hukum Islam. Dalam hal ini maqashid atau tujuan dari dimunculkannya suatu hukum Islam itu merupakan inti dari hukum Islam itu sendiri. Kebertujuan hukum Islam ini mengkover kelima fitur sistem hukum Islam di atas yakni sifat kognitif, keutuhan, keterbukaan, keterkaitan antar tingkatan, maupun multi-dimensionalitas. ${ }^{41}$

Jadi antara keenam fitur pendekatan sistem tersebut saling berkaitan satu sama lain, dengan kebertujuan sebagai intinya. Hal ini dikarenakan apapun fitur itu disusun dalam rangka untuk mencapai tujuan.

\section{c. Pendekatan Multidisipliner}

Pendekatan multidisipliner yang digunakan oleh Jasser Auda dalam mengkaji maqashid al-syari'ah yaitu bahwa dalam mengembangakan maqashid al-syari'ah sebagai suatu disiplin teori hukum Islam maka sangat dibutuhkan disiplin-disiplin ilmu lain atau konsep-konsep keilmuan lain.

\footnotetext{
${ }^{40}$ Ibid., hlm. 50-51

${ }^{41}$ Ibid., hlm. 54
} 
Karena jika tidak dilakukan pendekatan multidisipliner, maka teori hukum Islam akan selalu berada dalam kerangka literatur tradisional sihingga keputusan yang bersumber pada hukum Islam akan selalu ketinggalan jaman. $^{42}$

Hal ini terlihat dari pemikiran Auda yang dalam mengembangkan maqashid al-syariah tidak hanya didasarkan pada ilmu fiqh dan ushul fiqh saja, melainkan dia menggunakan teori-teori dari ilmu hadits, tafsir, bahkan teori kognitif, teori klasifikasi, teori sistem, filsafat, dan lain sebagainya. Inilah yang membedakan Jasser Auda dengan ulama hukum Islam klasik yang pada umumnya jika mengkaji hukum Islam maupun maqashid al-syariah hanya dikaitkan dengan ilmu-ilmu agama saja, sedangkan Auda mengkaitkannya dengan disiplin keilmuan meskipun itu dari barat tetapi jika dianggap relevan dan tidak bertentangan Islam maka oleh Auda dianggap perlu untuk dijadikan landasan analisisnya.

\section{Pemikiran Kontemporer Jasser Auda}

1) Peninjauan kembali Hukum Islam

Menurut Auda, adakah yang salah dengan "hukum Islam" hingga ia dijadikan kambing hitam atas permasalahan-permasalahan kemanusiaan yang terjadi. Menurutnya ada 3 hal yang harus ditinjau kembali yaitu:

a) Jika yang dimaksud dengan "hukum Islam" adalah syari'ah yaitu wahyu yang telah diterima Muhammad SAW yang dipraktikkan sebagai pesan dan misi hidupnya, yaitu, Al-Quran dan tradisi kenabian, maka sesungguhnya tidak ada yang salah. Hal ini dikarenakan kebenaran alQur'an bersifat mutlak.

b) Jika yang dimaksud dengan "hukum Islam" adalah fiqh yaitu kumpulan mengenai pendapat hukum yang diberikan oleh berbagai ahli hukum dari berbagai mazhab pemikiran, dalam hal penerapan syari'ah (atas) terhadap berbagai situasi kehidupan nyata mereka selama empat belas abad yang lalu, juga tidak salah, hal ini dikarenakan antar ulama fiqih saling memberikan koreksi dan tidak mungkin mereka bersepakat untuk sesuatu yang salah.

c) Jika yang dimaksud dengan "hukum Islam" adalah fatwa yaitu aplikasi dari syari'ah dan fiqih pada kehidupan umat Islam saat ini, maka jawabannya tergantung pada fatwa itu merupakan manifestasi dari Islam dan nilai moral atau manifestasi dari sesuatu yang salah dan bukan Islam. Jika fatwa itu berlandaskan pada sumber Islam yang outentik yakni al-Qur'an dan hadits maka fatwa itu akan benar. Tetapi jika bersumber pada sesuatu

${ }^{42}$ Ibid., hlm. 249 
yang salah dan bukan nilai-nilai Islam maka bisa saja fatwa tersebut salah. 43

Jadi, jika terjadi praktik-praktik kriminalitas yang mengatasnakaman "hukum Islam" sesungguhnya itu suatu kesalahan besar, karena ajaran Islam tidak pernaha ada yang mengisyaratkan sedikitpun untuk melakukan tindakan kriminal atau ketidakmanusiaan. Justru hukum Islam merupakan kemudi yang menjadi penggerak masyarakat yang adil, berdaya cipta, berkembang, manusiawi, spiritual, bersih, kohesif, ramah, dan sangat demokratis. Jika sampai terjadi praktik ketidakmanusiaan berdalih pada "hukum Islam" maka sesungguhnya pelakunya lah yang tidak memahami ajaran Islam dengan sesungguhnya atau malah ingin menghancurkan Islam itu sendiri dengan menjadikan "hukum Islam" sebagai kambing hitam.

2) Klasifikasi Maqashid al-Syari'ah menurut Ulama Klasik dan Menurut Jasser Auda (Kontemporer)

Secara bahasa, "maqshid" (jamaknya maqashid) berarti tujuan, prinsip, maksud, dan akhir. "Maqashid" hukum Islam berarti tujuan di balik keputusan-keputusan atau hukum secara Islami. ${ }^{44}$ Jadi maqashid al-syariah adalah tujuan dibalik ditetapkannnya hukum-hukum Islam. Sehingga "maqashid" di sini bisa diartikan sebagai sebuah "hikmah" di balik ditetapkannya hukum Islam.

Para ulama klasik, sebenarnya sudah banyak yang merumuskan klasifikasi dan bahkan menghierarkikan maqashid al-syari'ah. Misalnya saja hierarki maqashid al-Syariah yang dirumuskan oleh al-Syatibi dalam karyanya yang berjudul al-Muwaffaqat sebagaimana dikutip oleh Jasser Auda berikut ini:

${ }^{43}$ Ibid., hlm. xxiii

${ }^{44}$ Jasser Auda, Maqasid al-Shariah as Philosophy of Islamic Law: A Systems Approach, (digital book), (London: the International Institut of Islamic Thougth, 2007), hlm. 2 


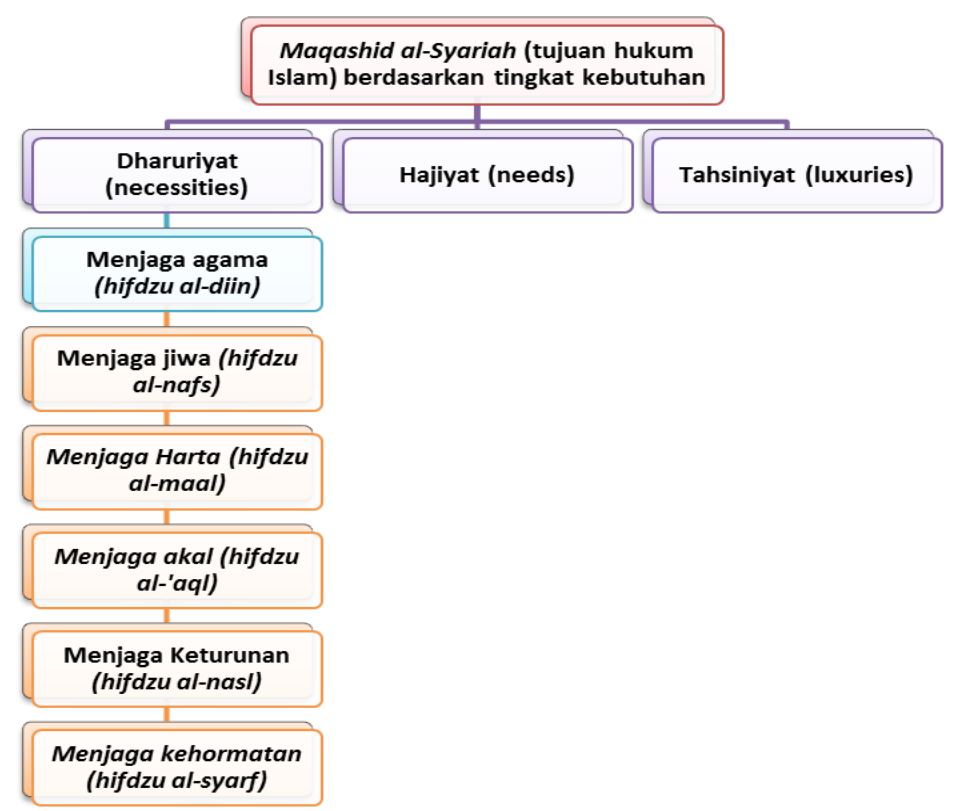

\section{Gambar 2. Klasifikasi Maqashid al-Syariah Klasik}

Menurut Al-Syatibi ada 3 tingkatan kebutuhan yang menjadi tujuan dari hukum Islam yaitu dharuriyat (necessity), hajiyat (need), dan tahsiniyat (luxuries). Dharuriyat sebagai kebutuhan paling mendasar terdiri dari hifdzu al-diin (menjaga agama), hifdzu al-nafs (menjaga jiwa), hifdzu al- maal (menjaga harta), hifdzu al-aql (menjaga akal), hifdzu al-nasl (menjaga keturunan) ${ }^{45}$ dan hifdzu al-syarf (menjaga kehormatan) ${ }^{46}$. Menurut as-Syatibi, masing-masing tingkatan melayani dan melindungi level di bawahnya dan begitu seterusnya sehingga pada setiap tingkatan memiliki hubungan yang erat. ${ }^{47}$

Menurut Auda, maqashid al-syariah klasik yang lebih bersifat individual yakni protection (perlindungan) dan perservation (pelestarian) itu harus direorientasikan menjadi maqashid yang lebih bersifat nilai universal, lebih bersifat kemasyarakatan dan kemanusiaan (hak asasi manusia dan kebebasan). ${ }^{48}$ Oleh karena itu, Jasser Auda muncul sebagai salah satu tokoh

${ }^{45}$ Lima ini sebaga maqashid dasar yang populer dan disetujui oleh mayoritas ulama.

46 Beberapa ulama diantaranya al-Syatibi menambahkan hifdz al-syarf (menjaga kehormatan ini) juga sebagai maqashid al-Syari'ah.

47 Jasser Auda, Maqasid al-Shariah as Philosophy of Islamic Law: A Systems Approach, (digital book), (London: the International Institut of Islamic Thougth, 2007), hlm. 3

${ }^{48}$ Ibid., hlm. 248 
kontemporer maka beliau membuat klasifikasi/hierarki maqashid alSyaria'ah kontemporer menjadi 3 tingkatan yaitu:

a) Genaral maqashid yaitu maqashid yang ditujukan pada keseluruhan hukum Islam termasuk di dalamnya dzaruriyat dan hajiyyat dengan ditambah tujuan maqashid yang baru yaitu keadilan dan fasilitasi;

b) Partial maqashid yaitu maqashid yang ditujukan pada keputusan tertentu, seperti tujuan untuk menemukan kebenaran dalam mencari sejumlah saksi dalam kasus pengadilan tertentu, tujuan untuk mengurangi kesulitan dalam membiarkan orang yang sakit untuk berbuka puasa, dan tujuan untuk memberi makan orang miskin dalam hal melarang orang-orang Muslim untuk menyimpan daging selama hari-hari raya Idul adha.

c) Spesific maqashid yaitu maqashid yang ditujukan pada bagian tertentu dari hukum Islam, misalnyakesejahteraan anak dalam keluarga, pencegahan kriminal dalam hukum pidana, pencegahan monopoli dalam hukum transaksi keuangan. ${ }^{49}$

Untuk mempermudah pemahaman mengenai klasifikasi maqashid alsyari'ah kontemporer, dapat dilihat dari gambar berikut:

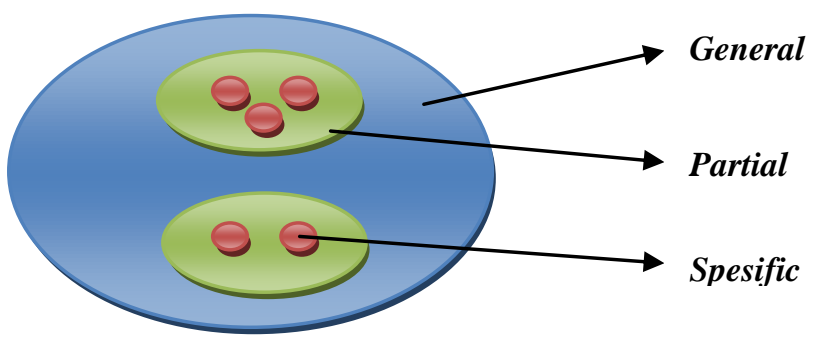

Gambar 3. Klasifikasi Maqashid al-Syariah Kontemporer ${ }^{50}$

Jika dilihat dari gambar di atas, maka klasifikasi maqashid al-syari'ah kontemporer yang ditawarkan oleh Jasser Audah lebih bersifat holistik (menyeluruh) dan mencakup hal-hal yang spesifik dan partial yang ini tidak dikaji dalam maqashid klasik.

3) Reorientasi Maqashid al-syariah dari perspektif klasik menuju perspektif kontemporer

Reorientasi maqashid al-syari'ah klasik menuju maqashid al-syari'ah kontemporer menurut Jasser Auda yaitu adanya perubahan dari maqashid alsyari'ah klasik yang bersifat "protection" (perlindungan) dan "preservation" (pelestarian) menuju maqashid al-syari'ah yang bersifat "development"

\footnotetext{
${ }^{49}$ Ibid., hlm. 5

${ }^{50}$ lbid., hlm 7
} 
(pengembangan ) dan "right" (kebebasan) ${ }^{51}$ dapat digambarkan dalam bagan sebagai berikut: ${ }^{52}$

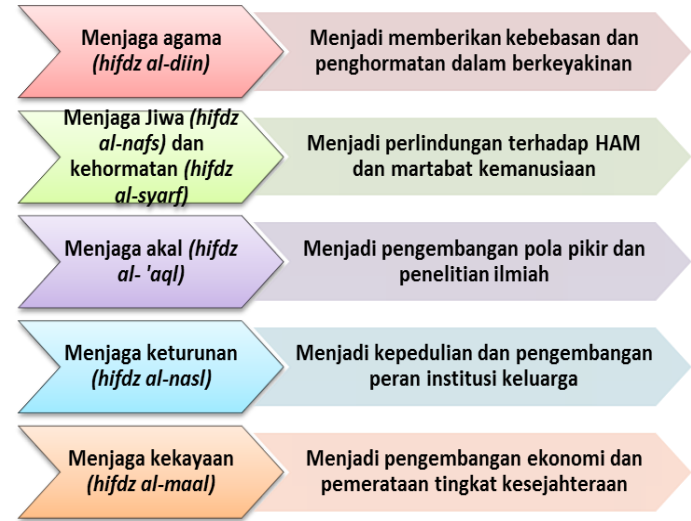

\section{Gambar 4. Reorientasi Maqashid Klasik menuju Maqashid Kontemporer}

Dari gambar di atas dapat dilihat pengembangan maqashid klasik yang dilakukan oleh Jasser Auda menuju maqashid kontemporer. Pengembangan maqashid tersebut oleh Auda tidak terlepas dari latar belakang pemikirannya yang menganggap bahwa kondisi kemanusiaan umat Islam saat ini sangat memprihatinkan sehingga memerlukan adanya pengembangan manusia sebagai tujuan utama dari maqashid itu sendiri.

Jika maqashid klasik lebih bersifat usaha pencegahan ,maka maqashid kontemporer Jasser Auda lebih bersifat pengembangan dan pemberian perlindungan terhadap hak asasi manusia, dan ini sesuai dengan kebutuhan dan permasalahan yang dialami oleh umat Islam saat ini. Kemudian jika maqashid klasik lebih bersifat individual maka maqashid kontemporer ini lebih mengedepankan aspek sosial kemasyarakatan.

Hal ini dikarenakan apapun usaha suatu hukum untuk mencegah timbulnya pelanggaran tetapi jika human resourcesnya tidak dikembangkan maka usaha itu kurang efektif atau bahkan sia-sia. Apalagi jika dihadapkan dengan perkembangan zaman yang semakin modern ini di mana tidak ada lagi batas antar wilayah dalam kaitannya dengan teknologi dan informasi yang berdampak pada kehidupan sosial budaya umat manusia. Oleh karena itu hukum dalam hal ini termasuk hukum Islam harus menyesuaikan dengan perkembangan zaman tanpa meninggalkan kaidah-kaidah hukum Islam yang telah ada. Misalnya salah satu upaya hukum Islam untuk menjaga harta dari pencurian yaitu dengan adanya hukum potong tangan ataupun hukumamn

\footnotetext{
${ }^{51}$ Ibid., hlm. 21-23

52 Ibid., hlm. 248
} 
penjara dan lain sebagainya. Tetapi lebih dari itu memeratakan tingkat kesejahteraan dan pendidikan akan lebih efektif dalam menaggulangi tindak pencurian.

Memang sepertinya Jasser Auda ini menerapkan adagium yang sudah banyak dikenal oleh umat Islam namun dengan pergantian susunan yaitu:

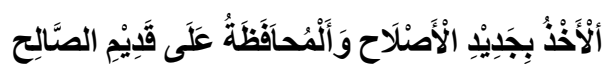

"Mengambil (pemikiran) yang baru yang lebih baik namun tetap menjaga (pemikiran) terdahulu yang baik".

Jasser Auda tidak menolak atau mengabaikan maqashid al-syariah klasik, tetapi ia mengkritisi dan kemudian mengembangkan menjadi maqashid kontemporer yang lebih universal, holistic, humanis dan sistematis yang esensinya sebenarnya memuat maqashid klasik namun dia lebih mengedepankan aspek kontemporer yang dianggapnya lebih baik.

\section{Relevansi Pemikiran Jasser Auda terhadap Pendidikan Islam}

Pemikiran kontemporer Jasser Auda mengenai pendekatan sistem multidisipliner ini sangat relevan jika diaplikasikan dalam pengembangan Pendidikan Agama Islam (PAI). Hal ini dikarenakan pendidikan Agama Islam yang juga merupakan sebuah sistem yakni terdiri dari berbagai unsur yang saling berkaitan satu sama lain dan bertujuan. Sistem pendidikan Agama Islam yang dalam hal ini bisa terdiri dari unsur pendidik, peserta didik, kurikulum, pembelajaran maupun tujuan dari PAI itu akan lebih efektif jika dikembangkan melalui pendekatan sistem multidisipliner.

Selama ini, pengembangan pendidikan Agama Islam khusunya di Indonesia masih belum menggunakan pendekatan sistem. Hal ini terbukti dari upaya pemerintah sendiri dalam mengembangkan pendidikan termasuk pendidikan Agama Islam lebih menekankan aspek pengembangan kurikulum. Berapa kali kurikulum pendidikan diubah dalam rangka pengembangannya dengan maksud agar kualitas pendidikan ini semakin meningkat. Tetapi di sisi lain, pengembangan kualitas SDM baik itu pendidikan dan peserta didik masih belum terlalu diupayakan. Hal ini terbukti dari perhatian pemerintah terhadap pengembangan keompetensi pendidik dan peserta didik, misalnya pengembangan riset dan karya ilmiah masih belum maksimal.

Keenam fitur sistem yang ditawarkan oleh Auda, yakni sifat kognitif, keutuhan, keterbukaan, keterkaitan hirarki, multidimensionalitas, dan kebertujuan ini sangat relevan dengan sistem pendidikan Agama Islam itu sendiri. Mislanya jika melihat dari berbagai pendapat para ahli pendidikan Islam, kebertujuan (tujuan utama) pendidikan Islam adalah menjadikan manusia berkembang keseluruhan potensinya dalam rangka menjalankan 
perannya sebagai Abdullah dan khalifatullah. Yakni untuk menjadikan manusia shalih secara individu maupun secara sosial. Dan ini sangat relevan dengan pengembangan maqashid al-syari'ah Jasser Auda dari maqashid klasik yang lebih bersifat individual menuju maqashid kontemporer yang lebih bersifat humanis dan social kemasyarakatan.

Tujuan pendidikan Islam ini akan dapat dicapai jika adanya keterkaitan dan kesinambungan antara sifat kognitif pendidikan Islam, keutuhan pendidikan Agama Islam sebagai suatu sistem, keterbukaan pendidikan Agama Islam karena seiring perkembangan zaman maka pendidikan Agama Islam harus mampu menjawab tantangan dan membaca peluang di era globalisasi ini, dimensi pendidikan Islam antara lain aqidah, akhlak, al-Qur'an, ibadah maupun sejarah.

Selanjutnya pendekatan multidisipliner yang digunakan oleh Jasser Auda dalam mengkaji maqashid al-syari'ah juga sangat relevan jika digunakan untuk mengkaji pendidikan Agama Islam. Hal ini dikarenakan sebagai suatu sistem, pendidikan Agama Islam tidak bisa terlepas dari disiplin ilmu lain, seperti filsafat, tasawuf, psikologi, sains, ekonomi, sosiologi, antropologi, geografi dan lain sebagainya. Misalnya dalam kaitannya dengan perkembangan peserta didik maka PAI butuh teori-teori perkembangan dalam psikologi perkembangan. Kemudian kaitannya dengan penjelasan ayat-ayat kauniyah dalam al-Qur'an maka PAI butuh sains seperti fisika, kimia, matematika, geografi dan biologi sebagai pendukungnya. Kemudian terkait dengan ibadah dan muamalah maka PAl butuh ilmu sosiologi, antropologi, ekonomi dan lain sebagainya.

Pemikiran kontemporer Jasser Auda ini memang sangat relevan jika digunakan untuk pengembangan pendidikan Agama Islam baik dalam aspek pengembangan secara teoritik maupun praktis. Memang hanya saja segala sesuatu yang baru, baik itu berupa pengembangan, inovasi, maupun perubahan menuju sesuatu yang lebih baik pasti akan menuai pro dan kontra. Terlepas dari pro-kontra maupun kritik, sesungguhnya keberanian untuk berijtihad itu sudah dinilai satu pahala meskipun ijtihad itu salah. Wallahu a'lam bi al-shawab

\section{Penutup}

Pemikiran kontemporer Jasser Auda mengenai maqashid al-Syariah ini dilatarbelakangi oleh pandangannya terhadap maqashid al-syariah klasik lebih bersifat individual, dan mengedepankan aspek protection dan preventation, kurang humanis dan tidak berkebebasan (kurang terbuka) sehingga maqashid al-syari'ah klasik ini dianggap kurang memenuhi tuntutan perubahan zaman yang semakin berkembang pesat. Belum lagi tingkat kemajuan umat Islam di berbagai Negara masih rendah jika diukur dari segi 
pendidikan, kesejahteraan, partisipasi politik, ekonomi dan pemberdayaan atau emansipasi wanita. Oleh karena itu melalui pendekatan sistem multidisipliner sebagai metodologi dan filsafat sistem sebagai pisau analisis, maka maqashid al-syari'ah diposisikan sebagai filsafat hukum Islam Melalui pendekatan sistem ini, Jasser Auda mengembangkan maqashid al-syariah kontemporer yang lebih bersifat universal, holistik, terbuka, humanis dan menuju ke arah pengembangan sumber daya manusia. Pendekatan sistem yang ditawarkan oleh Jasser Auda yaitu pendekatan sistem yang meliputi 6 fitur yakni sifat kognitif (cognitive nature), keutuhan (wholeness), keterbukaan (openfulness), keterkaitan hirarki (interrelated hierarchy), multidimensionalitas (multidimensionality) dan kebertujuan (purposefulness). Adapun pendekatan multidisipliner digunakan oleh Auda dalam rangka mengkaji maqashid al-syari'ah sebagai tujuan dari produk "hukum Islam" kaitannya dengan filsafat, fiqh, ushul fiqh, ilmu tafsir, ilmu hadits, ilmu kalam, ilmu perkembangan kognitif (cognitive science) dan lain sebagainya.

Pemikiran kontemporer Jasser Auda ini sangat relevan terhadap pengembangan pendidikan Agama Islam baik secara teoritis maupun praktis. Hal ini dikarenakan PAI juga merupakan suatu sistem yang terdiri dari berbagai komponen atau unsure (pendidik, peserta didik, kurikulum, pembelajaran, institusi, dan lain sebagainya) yang saling berkaitan dalam rangka mencapai tujuan PAl itu sendiri yakni membentuk manusia yang shaleh secara individu (Abdullah) maupun sosial (khalifatullah). Oleh karena itu 6 fitur dalam filsafat sistem serta multidisipliner yang ditawarkan Auda itu sangat relevan terhadap pengembangan pendidikan Agama Islam (PAI).

\section{Daftar Rujukan}

Auda, Jasser, Maqasid al-Shariah as Philosophy of Islamic Law: A Systems Approach, (digital book), London: the International Institut of Islamic Thougth, 2007.

Auda, Jasser, Al-Maqasid untuk Pemula, Terj. Ali Abdelmo'im.Yogyakarta: SUKA-Press, 2013.

Bakhtiar, Amsal, Filsafat Ilmu, Jakarta: Rajawali Pers, 2010.

Daulay, Haidar Putra, Pemberdayaan Pendidikan Islam di Indonesia, Jakarta: Rineka Cipta, 2009

Ferdiansyah, Hengki, Jasser Auda Imam al Ghazali Masa Kini, (online), Tersedia : http://www.muslimedianews.com/2016/08/jasser-audaimam-al-ghazali-masa-kini.html, diakses 30 November 2017 
Kamus Besar Bahasa Indonesia (KKBI) (online), Tersedia : https://kbbi.web.id/sistem, diakses 30 November 2017

Muhadjir, Noeng, Filsafat Ilmu: Ontologi, Epistemologi, Axiologi, Yogyakarta: Penerbit Rake Sarasin, 2011. Mustansyir, Rizal dan Misnal Munir, Filsafat IImu, Yogyakarta: Pustaka Pelajar, 2008.

Jasser Auda, Biografi Jasser Auda, (online), Tersedia : http://www.jasserauda.net/portal/biography/?lang=en, diakses 30 November 2017

Sulaiman, King Faisal. Maqasid Al-Shariah Perspektif Jasser Auda, (http://kingfaisalsulaiman.com/maqasid-al-shariah-perspektif-jasserauda/), diakses 30 November 2017

Tafsir, Ahmad, Filsafat Umum, Bandung: Remaja Rosda Karya, 1990. 